\title{
ERRATUM
}

The following paper was published with the tables missing. The paper is republished in its entirety below.

\section{Insulin sensitivity is increased and fat oxidation after a high-fat meal is reduced in normal-weight healthy men with strong familial predisposition to overweight}

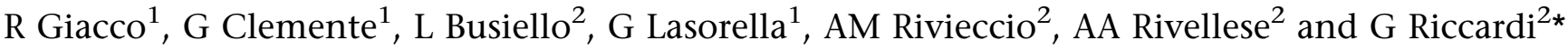 \\ ${ }^{1}$ Institute of Food Science and Technology of National Research Council, Avellino, Italy ${ }^{2}$ Department of Clinical and \\ Experimental Medicine, Federico II University, Medical School, Naples, Italy
}

OBJECTIVE: To evaluate whether postprandial abnormalities of energy expenditure and/or lipid oxidation are present in healthy, normal-weight subjects with a strong family history of obesity and thus at high risk to become obese.

DESIGN: Case-control study.

SUBJECTS: A total of 16 young healthy men participated in the study. Eight subjects had both parents overweight (father's and mother's body mass index (BMI) $>25 \mathrm{~kg} / \mathrm{m}^{2}$ ) and eight had both parents with normal body weight (father's and mother's $\mathrm{BMl}<25 \mathrm{~kg} / \mathrm{m}^{2}$, respectively). The group of subjects with overweight parents was similar to that with normal-weight parents (control group) in terms of BMI $\left(23.7 \pm 1.7\right.$ vs $\left.22.7 \pm 1.1 \mathrm{~kg} / \mathrm{m}^{2}\right)(\mathrm{M} \pm$ s.d.) and fat-free body mass (FFM) $(60.5 \pm 4.9 \mathrm{vs}$ $58.4 \pm 2.0 \mathrm{~kg}$ ), but was slightly older than the control group $(25.4 \pm 3.3$ vs $22.7 \pm 2.4 \mathrm{y} ; P<0.05)$.

MEASUREMENTS: Energy expenditure (EE) was measured by indirect calorimetry, and blood samples were taken for the evaluation of metabolic variables in the fasting state and every hour for $8 \mathrm{~h}$ after a standard fat-rich meal (protein 15\%, carbohydrate $34 \%$, fat $51 \%, 4090 \mathrm{~kJ})$.

RESULTS: Fasting plasma glucose, cholesterol, HDL-cholesterol, triglyceride, free fatty acid (FFA) and leptin concentrations were similar in both groups of participants, but subjects with overweight parents has significantly lower plasma insulin concentrations $(5.11 \pm 0.51$ vs $7.07 \pm 1.56 \mu \mathrm{U} / \mathrm{ml} ; P<0.007)$ and HOMA index of insulin resistance $(1.1 \pm 0.1$ vs $1.6 \pm 0.4 ; P<0.01)$. Postprandial plasma glucose, triglyceride, FFA and leptin concentrations were similar in the two groups, whereas insulin levels were significantly lower in the group with both parents overweight at 3, 5, 6, 7 and $8 \mathrm{~h}$. Fasting and postprandial EE, and fasting lipid and carbohydrate oxidation were similar in both groups. On the contrary, postprandial carbohydrate oxidation (incremental area under curve) was significantly higher $(196.25 \pm 94.75$ vs $75.88 \pm 74.72 \mathrm{mg} / \mathrm{kg} \mathrm{FFM} \times 8 \mathrm{~h} ; P<0.007)$ and that of lipid oxidation lower $(90.93 \pm 80.32$ vs $163.68 \pm 108.22 \mathrm{mg} / \mathrm{kg} \mathrm{FFM} \times 8 \mathrm{~h} ; P<0.05)$ in the group of subjects with overweight parents.

CONCLUSION: Normal-weight subjects with a strong family history of obesity present a reduced lipid oxidation in the postprandial period and a metabolic profile characterized by low plasma insulin levels and the HOMA index, which is compatible with increased insulin sensitivity. These metabolic characteristics may be considered as early predictors of weight gain and are probably genetically determined.

International Journal of Obesity (2004) 28, 342-348. doi:10.1038/sj.ijo.0802589

Keywords: energy expenditure; lipid oxidation; insulin sensitivity; indirect calorimetry

\section{Introduction}

The incidence of obesity is rising rapidly in Western countries, as is its prevalence among young people. ${ }^{1,2}$ Since obesity is an important risk factor for the development of

*Correspondence: Professor G Riccardi, Department of Clinical and Experimental Medicine, Federico II University, Medical School Via S. Pansini 5, 80131 Naples, Italy. E-mail: riccardi@unina.it coronary heart diseases, Type II diabetes, hypertension, dyslipidemias, stroke and cancer, a strategy directed to the prevention of these diseases must account for the factors involved in its etiology. ${ }^{3,4}$

In the last decade, evidence has accumulated showing that obesity is a disorder resulting from an interaction between genetic predisposition and some environmental factors related to food intake and physical exercise. ${ }^{5,6}$ Information 
on genetic factors involved in the development of obesity in humans derives from studies on populations, families and twins. $^{7-9}$ It is widely acknowledged that human obesity is a multifactorial, multigene disease and, although the identification of novel genes has been successful in animals, clinical investigation has not yet proven successful in finding the molecular causes of obesity in humans. This might be partly due to the large number of genes involved in the etiology of human obesity but might also be a consequence of environmental factors, which, compared to the genetic ones, are more relevant in the development of overweight. ${ }^{10}$

Among the environmental factors, total energy intake and diet composition play an important role. The amount of fat in the diet in many studies is positively correlated with the excess of body fat. ${ }^{11}$ As a matter of fact, in obese and postobese subjects a temporary increase in the amount of dietary fat is not associated with an increase in lipid oxidation, thus indicating an impairment of the oxidative metabolism of fat. ${ }^{12}$ In longitudinal studies, low-fat oxidizers show a greater risk of gaining body weight than high-fat oxidizers. ${ }^{13}$ Moreover, recent studies have demonstrated that postobese individuals have a higher respiratory quotient (RQ) - which indicates a low rate of fat oxidation - than individuals who have been constantly lean; among them, those experiencing a weight relapse are, once again, low-fat oxidizers. ${ }^{14}$

Nevertheless, the results of these studies do not explain whether the abnormal lipid oxidation observed in obese or postobese subjects is genetically determined or acquired. Moreover, it is not clear whether this condition is paralleled by abnormalities in the hormonal and metabolic profiles obviously involved in the regulation of substrate oxidation. To clarify this issue, it might be appropriate to evaluate lipid oxidation in normal-weight subjects who have never been obese but have a high risk, possibly genetically determined, to develop obesity. As a matter of fact, it has been shown that parental obesity increases the risk to become an obese adult by more than two-fold in either obese or nonobese children. ${ }^{15}$ Against this background, the aim of the present study was to evaluate whether abnormalities of energy expenditure and/or lipid oxidation both in the fasting state and after a high-fat meal are present in healthy, normal-weight subjects with a strong family history of obesity, and therefore with a strong genetic risk to become obese. A further aim was to evaluate their metabolic and hormonal profiles in order to establish possible links between oxidative metabolism and plasma concentrations of relevant substrates and hormones.

\section{Subjects and methods}

A total, 16 young healthy men (age $23.7 \pm 3.32 \mathrm{y})(\mathrm{M} \pm$ s.d.) participated in the study. Eight subjects had both parents overweight (measured father's and mother's body mass index (BMI) $>25 \mathrm{~kg} / \mathrm{m}^{2}$ ) and eight had both parents with normal body weight (measured father's and mother's BMI $<25 \mathrm{~kg}$ / $\mathrm{m}^{2}$ ) (Table 1); participants' body weight was within the
Table 1 Participants' characteristics

\begin{tabular}{lcc}
\hline & $\begin{array}{c}\text { Both parents overweight } \\
\text { Both parents with } \\
\text { normal body weight }\end{array}$ \\
\hline No./gender & $8 / \mathrm{M}$ & $8 / \mathrm{M}$ \\
Age $(\mathrm{y})$ & $25.4 \pm 3.3$ & $22.7 \pm 2.4^{*}$ \\
$\mathrm{BMI}\left(\mathrm{kg} / \mathrm{m}^{2}\right)$ & $23.7 \pm 1.7$ & $22.7 \pm 1.1$ \\
$\mathrm{FFM}(\mathrm{kg})$ & $60.5 \pm 4.9$ & $58.4 \pm 2.0$ \\
$\mathrm{FM}(\mathrm{kg})$ & $15.8 \pm 3.0$ & $14.1 \pm 2.5$ \\
Measured father's BMI $\left(\mathrm{kg} / \mathrm{m}^{2}\right)$ & $30.4 \pm 1.6$ & $24.6 \pm 1.2^{\star *}$ \\
Measured mother's BMI $\left(\mathrm{kg} / \mathrm{m}^{2}\right)$ & $29.2 \pm 1.1$ & $22.4 \pm 0.8^{* *}$ \\
\hline
\end{tabular}

${ }^{*} P<0.05 ;{ }^{* \star} P<0.02$. Values are expressed as $M \pm$ s.d.

normal range $\left(\mathrm{BMI}<25 \mathrm{~kg} / \mathrm{m}^{2}\right)$ and all had been weight stable in the 3 years prior to the study. None of the subjects in either group performed strong or competitive physical activity nor did they take any type of medication. Subjects with a family history of Type II diabetes or other endocrine diseases were excluded from the study. The group of subjects with both parents overweight was slightly older than the one with both parents with normal weight (control group) but similar in terms of BMI, fat-free body mass (FFM) calculated according to Kotler's equation (see Methods) and fat mass (FM) calculated subtracting FFM from body weight (Table 1).

Each participant filled a 7-day food record the week before the experiment and personally handed it to a dietitian who checked its completeness. Diet composition was evaluated by the food composition tables. ${ }^{16}$

Physical activity was assessed by a questionnaire that ranked individuals in four classes for physical activity at work and four classes for physical activity during leisure time. ${ }^{17}$ Participants gave their written informed consent to the protocol, which had been approved by the Ethics Committee of the 'Federico II' University Medical School.

\section{Test meal}

On the day of the experiment, the participants consumed a standard fat-rich meal (protein 15\%, carbohydrate 34\%, fat $51 \%, 4090 \mathrm{~kJ}$ ) in which about $50 \%$ of the fat content was represented by saturated fatty acids. The composition of the test meal resembles that of other test meals utilized for similar purposes. ${ }^{12,18}$ It was composed exclusively of natural foods: a potato-pie plus a banana $(120 \mathrm{~g})$. The potato-pie was prepared with $300 \mathrm{~g}$ of potatoes, $60 \mathrm{~g}$ of skimmed milk, $25 \mathrm{~g}$ of egg, $50 \mathrm{~g}$ of cheese, $40 \mathrm{~g}$ of salami, $5 \mathrm{~g}$ of olive oil and $18 \mathrm{~g}$ of butter; it was prepared by the staff of the metabolic kitchen and its composition was calculated using the food composition tables issued by the Italian National Institute of Nutrition. ${ }^{16}$ Participants were asked to consume the meal within $15 \mathrm{~min}$.

\section{Study design}

All participants were scheduled to come to the Research Centre at $08.00 \mathrm{~h}$ after a $12 \mathrm{~h}$ fast; an intravenous catheter 
was inserted in an antecubital vein for blood sampling, and kept patent by saline infusion.

All participants underwent indirect calorimetry on the morning of the experiment for $1 \mathrm{~h}$ before the test meal and for $8 \mathrm{~h}$ after the test meal, with two 1-h intervals at the fourth and seventh hour. Blood samples were taken at fasting and every hour for $8 \mathrm{~h}$ after the test meal to measure glucose, insulin, cholesterol, triglyceride and free fatty acid (FFA) plasma concentrations. Plasma leptin levels were measured at fasting and every $2 \mathrm{~h}$ after the test meal. A $24 \mathrm{~h}$ urine sample was collected on the day of the experiment to measure urea concentration. Urinary nitrogen concentration was obtained by conversion of urea nitrogen. Participants in the study were asked to consume a standard isoenergetic diet (protein $15 \%$, carbohydrate $55 \%$, fat $30 \%$ ) and to abstain from vigorous physical activity on the day before the experiment.

\section{Methods}

Indirect calorimetry was performed by Deltatrac ${ }^{\mathrm{TM}}$ II (Datex, Division of Instrumentarium Corp. , Helsinki, Finland) using a transparent ventilated hood. Room air was drawn through the ventilated canopy at a fixed flow rate $(401 / \mathrm{min})$. A constant fraction of the air flowing out of the hood was continuously collected and analyzed for oxygen and carbon dioxide by a differential paramagnetic sensor and infrared carbon dioxide analyzer, respectively. The instrument, after warm-up, was calibrated before each test with a standardized gas mixture $\left(5.0 \% \mathrm{CO}_{2}\right.$ and $\left.95 \% \mathrm{O}_{2}\right)$ and monthly with ethanol combustion. The coefficient of variation of the combustion tests was $1.5 \%$. Computed values for oxygen and carbon dioxide exchange were corrected at standard temperature, pressure and humidity. Oxygen consumption and carbon dioxide production were measured at 1-min intervals and resting energy expenditure (REE) and substrate oxidation were calculated on the mean of all measurements with exclusion of the first 15 min of test (adaptment phase). REE, carbohydrate and lipid oxidation rates and nonproteic respiratory quotient (NPRQ) were calculated from oxygen consumption, carbon dioxide production and $24 \mathrm{~h}$ urinary nitrogen excretion according to Weir ${ }^{19}$ formulas. The mean coefficient of variation for repeated measurements of intraindividual REE in our laboratory was $2.4 \%$.

A bioelectrical impedance analyser (STA/BIA Akern) was used for the measurement of resistance $(R)$ and reactance $(X)$ of body tissue; these parameters, together with body weight and height, were used to calculate each participant's FFM according to Kotler's equation $\left(0.5 \times \text { height }(\mathrm{cm})^{1.48} /\left(\sqrt{(} R^{2}+X^{2}\right)\right)^{0.55} / 1.21+0.42 \times$ weight + $0.49) .{ }^{20} \mathrm{FM}$ was calculated subtracting FFM from body weight. The measurements were performed according to a standard protocol in the morning of the experiment after a $12 \mathrm{~h}$ fast. ${ }^{21} R$ and $X$ were measured at the flow of a $50-\mathrm{kHz}$ injected mono-frequency current with a coefficient of variance $<1.5 \%$.

Plasma glucose, cholesterol, triglyceride and FFA concentrations were measured by standard enzymatic-colorimetric methods (Boehringer Mannheim, Mannheim, Germany); insulin and leptin concentrations were analyzed by radioimmunoassay methods. ${ }^{22}$ Urinary urea concentrations were measured by the standard enzymatic method (ABX Diagnostics, Montpellier). The HOMA index was calculated by multiplying fasting plasma glucose $(\mathrm{mmol} / \mathrm{l})$ by fasting plasma insulin $(\mu \mathrm{U} / \mathrm{ml})$ concentrations divided by $22.5 .^{23}$

\section{Statistical analysis}

All data are expressed as means \pm s.d. REE and substrate oxidation corrected for fat-free mass were calculated dividing REE and substrate oxidized, respectively, by FFM. Postprandial changes in NPRQ were calculated subtracting the basal measurements from each value at different times. Postprandial incremental area under the curve was calculated for REE and substrate oxidation utilizing the trapezoidal method after subtraction of the basal value for each postprandial measurement. Student's unpaired $t$-test was used to compare differences in plasma metabolites between the two groups of subjects; energy expenditure, NPRQ and substrate oxidation were evaluated both at fasting and in the postprandial period by a nonparametric test for two independent samples (Mann-Whitney). The data were analyzed with the use of SPSS 11.0 (SPSS Inc., Chicago, IL, USA). Statistical significance was checked by setting the level of significance at $P=0.05$ (two-tailed).

\section{Results}

The two groups showed similar energy intake and dietary composition as estimated by a 7-day food record. The daily energy intake of the participants' habitual diet was $10289 \pm 2399$ and $9395 \pm 2683 \mathrm{~kJ}$, respectively, in the group with overweight parents and in the control group, with $14 \pm 1.8$ vs $13 \pm 1.9 \%$ of daily energy derived from protein, $47 \pm 2.1$ vs $48 \pm 2.4 \%$ from carbohydrate and $39 \pm 3.1$ vs $39 \pm 2.9 \%$ from fat, respectively. The polyunsaturated to saturated $(P / S)$ ratio was $0.34 \pm 0.06$ in the group with overweight parents and $0.31 \pm 0.09$ in the control group. The ratio between average energy intake and basal metabolic rate was $1.19 \pm 0.31$.

No difference was found between the two groups in the score calculated taking into account physical activity at work and during leisure time $(3.2 \pm 0.8$ vs $3.3 \pm 0.7$ score units, n.s.).

Fasting plasma glucose, cholesterol, HDL-cholesterol, triglyceride and FFA concentrations were similar in both groups of participants, but subjects with overweight parents had significantly lower plasma insulin concentrations $(5.11 \pm 0.51$ vs $7.07 \pm 1.56 \mu \mathrm{U} / \mathrm{ml} ; \quad P<0.007)$ and HOMA 
$(1.1 \pm 0.1$ vs $1.6 \pm 0.4 ; P<0.01)$ than the control group (Table 2).

Postprandially, plasma glucose levels decreased in both groups after the first and the second hour and then returned to baseline by the third hour; thereafter they remained relatively stable until the end of the experiment in both groups (Figure 1). At all time points, plasma glucose levels were not statistically different between the groups. Conversely, postprandial insulin levels were lower in the group with both parents overweight than in the controls and the difference was statistically significant at 3, 5, 6, 7 and $8 \mathrm{~h}$ (Figure 1).

Postprandial plasma FFA and triglyceride levels were similar in the group with overweight parents and in the control group (Figure 2).

Fasting plasma leptin concentrations were slightly lower in the group with overweight parents compared to the control group $(2.71 \pm 1.46$ vs $3.81 \pm 2.75 \mathrm{ng} / \mathrm{ml}, P=0.33)$, but the difference was not statistically significant. Postprandial plasma leptin levels decreased similarly in both groups and were not signicantly different in subjects with both parents overweight and in controls (Figure 1). Urinary nitrogen excretion in offspring of both parents overweight was $13.5 \pm 3.3 \mathrm{~g} / 24 \mathrm{~h}$ and in those with both parents with normal weight was $14.2 \pm 2.7 \mathrm{~g} / 24 \mathrm{~h}$.

In the fasting state, REE did not differ between the two groups (individuals with both parents overweight $128 \pm 10 \mathrm{~kJ} / \mathrm{kg}$ FFM/day $v s$ control group $128 \pm 12 \mathrm{~kJ} / \mathrm{kg}$ FFM/day). The oxidation of carbohydrate $(3230 \pm 750$ vs $4080 \pm 1260 \mathrm{mg} / \mathrm{kg} \mathrm{FFM} /$ day $)$ and lipid $(1150 \pm 570$ vs $740 \pm 550 \mathrm{mg} / \mathrm{kg} \mathrm{FFM} /$ day) was respectively lower and higher in the group with overweight parents although the differences were not statistically significant (Table 3). The postprandial incremental areas under the curve (IAUC) of REE, calculated for $8 \mathrm{~h}$ after the meal, were similar in the two groups $(4.31 \pm 1.70$ vs $4.07 \pm 2.41 \mathrm{~kJ} / \mathrm{kg} \mathrm{FFM} \times 8 \mathrm{~h})$ whereas substrate oxidations differed. As a matter of fact the NPRQ increased $1 \mathrm{~h}$ after the meal and thereafter declined in both groups; however, the postprandial changes in NPRQ (difference between each postprandial measurement and the baseline value) were constantly higher in the offspring of two overweight parents as compared with the control group

Table 2 Fasting metabolic parameters

\begin{tabular}{lcc}
\hline & Both parents overweight & $\begin{array}{c}\text { Both parents with } \\
\text { normal body weight }\end{array}$ \\
\hline Glucose $(\mathrm{mmol} / \mathrm{l})$ & $5.00 \pm 0.48$ & $4.99 \pm 0.31$ \\
Insulin $(\mu \mathrm{U} / \mathrm{ml})$ & $5.11 \pm 0.51$ & $7.07 \pm 1.56^{* *}$ \\
HOMA & $1.1 \pm 0.1$ & $1.6 \pm 0.4^{*}$ \\
FFA $(\mathrm{g} / \mathrm{l})$ & $0.11 \pm 0.06$ & $0.07 \pm 0.02$ \\
Cholesterol $(\mathrm{mmol} / \mathrm{l})$ & $4.62 \pm 0.85$ & $3.98 \pm 0.93$ \\
Triglyceride $(\mathrm{mmol} / \mathrm{l})$ & $1.03 \pm 0.45$ & $0.98 \pm 0.49$ \\
HDL-chol $(\mathrm{mmol} / \mathrm{l})$ & $1.18 \pm 0.15$ & $1.18 \pm 0.18$ \\
Leptin $(\mathrm{ng} / \mathrm{ml})$ & $2.71 \pm 1.46$ & $3.81 \pm 2.75$ \\
\hline
\end{tabular}

${ }^{\star} P<0.01 ;{ }^{* \star} P<0.007$. Values are expressed as $M \pm$ s.d. and differences were statistically significant betweeen the second and the sixth hour (Figure 3 ). The higher postprandial NPRQ observed in the offspring of overweight parents was due to a higher contribution of carbohydrate and a lower contribution of fat to the postprandial oxidative process. As a matter of fact, carbohydrate oxidation evaluated as postprandial incremental area was higher in the group of subjects with overweight parents than in the control group, with a statistically significant difference between the two groups (IAUC: $196.25 \pm 94.75$ vs $75.88 \pm 74.72 \mathrm{mg} / \mathrm{kg} \quad \mathrm{FFM} \times 8 \mathrm{~h}$; $P<0.007$ ) (Table 3). Conversely, lipid oxidation (evaluated as postprandial incremental area) was lower in individuals with both parents overweight than in the control group (IAUC: $90.93 \pm 80.32$ vs $163.68 \pm 108.22 \mathrm{mg} / \mathrm{kg} \quad \mathrm{FFM} \times 8 \mathrm{~h}$; $P<0.05)$ (Table 3 ). Taking into consideration the intake of
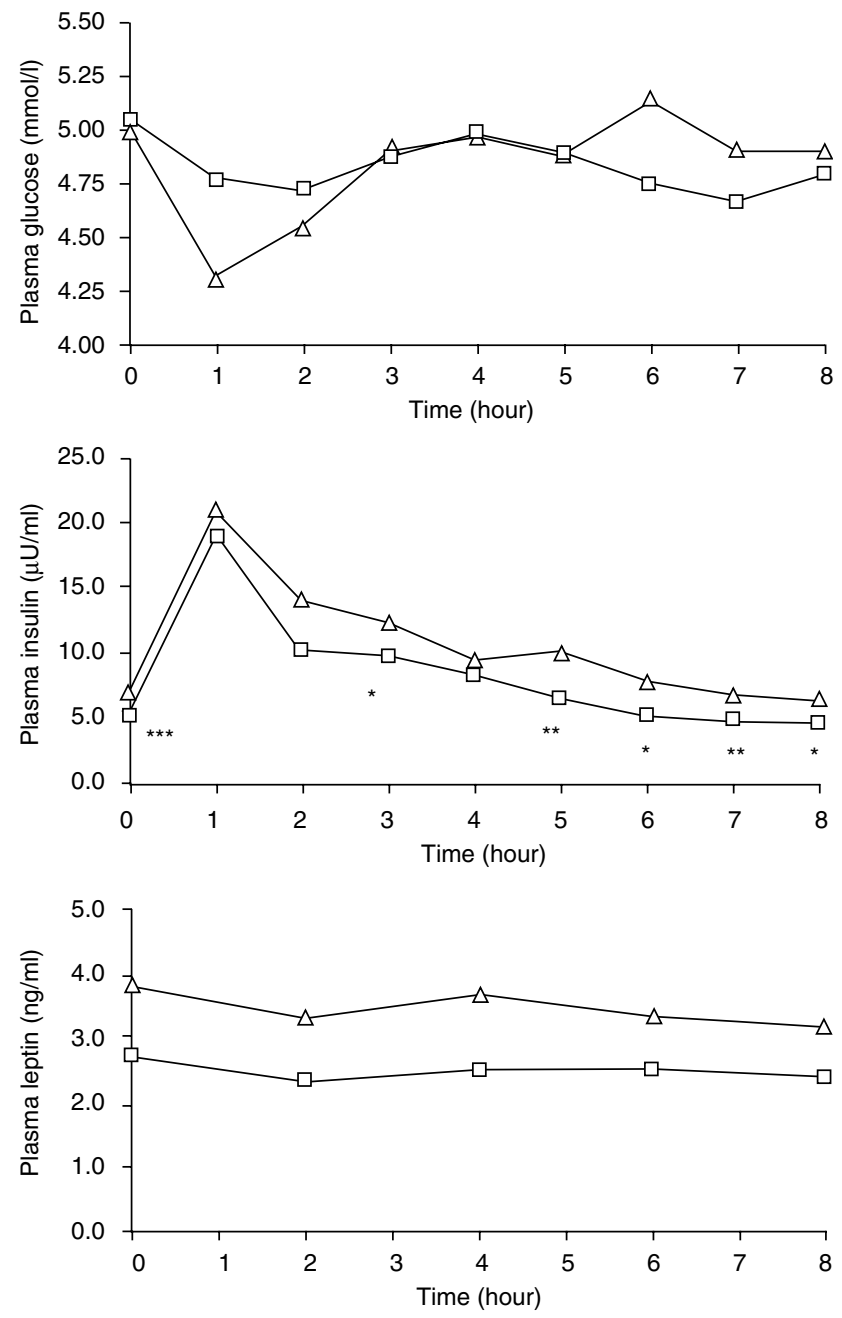

Figure 1 Postprandial plasma glucose (upper panel), plasma insulin (middle panel) and leptin (lower panel) levels after the standard fat-rich meal in lean subjects with normal-weight parents (triangle) and in those with both parents overweight (square). ${ }^{*} P<0.05$; ${ }^{* \star} P<0.03 ;{ }^{* *} P<0.01$; subjects with normalweight parents vs subjects with both parents overweight. 
346
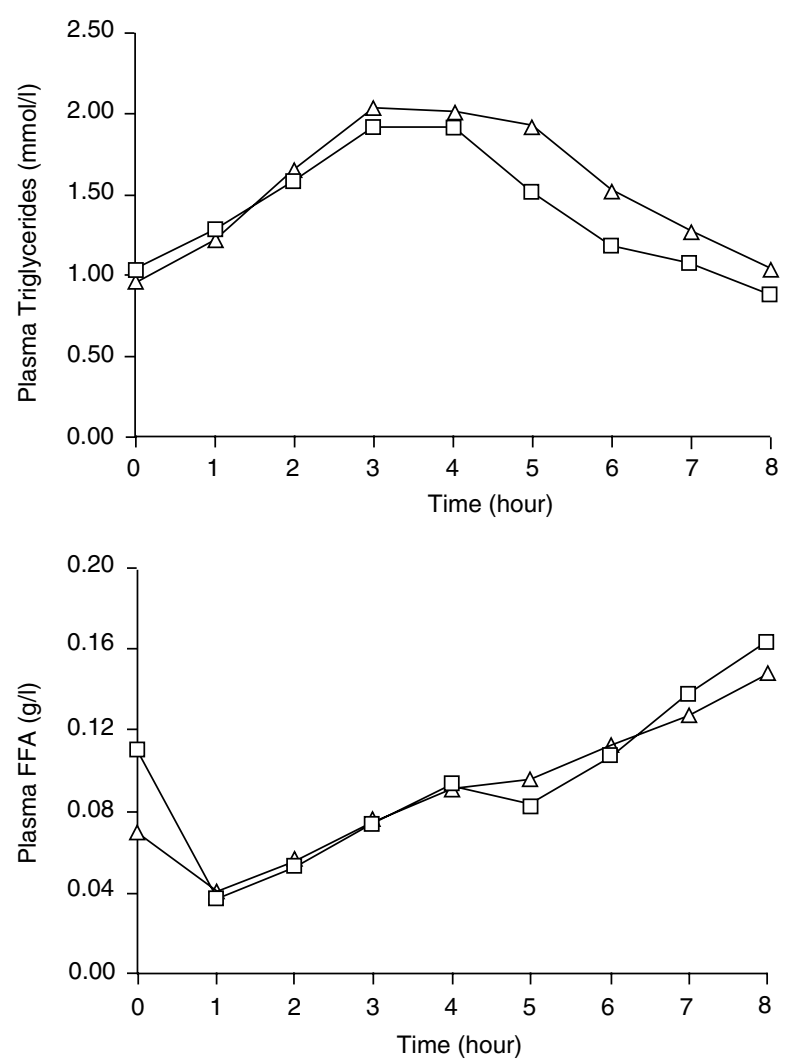

Figure 2 Postprandial plasma triglyceride (upper panel) and FFA (lower panel) levels after the standard fat-rich meal in lean subjects with normalweight parents (triangle) and in those with both parents overweight (square).

Table 3 Energy and oxidative metabolism

\begin{tabular}{lcc}
\hline & $\begin{array}{c}\text { Both parents } \\
\text { overweight }\end{array}$ & $\begin{array}{c}\text { Both parents with } \\
\text { normal body weight }\end{array}$ \\
\hline Fasting & $128 \pm 10$ & $128 \pm 12$ \\
Energy expenditure $(\mathrm{kJ} / \mathrm{kg} \mathrm{FFM} / \mathrm{d})$ & $3230 \pm 750$ & $4080 \pm 1260$ \\
CHO oxidation $(\mathrm{mg} / \mathrm{kg} \mathrm{FFM} / \mathrm{d})$ & $1150 \pm 570$ & $740 \pm 550$ \\
Lipid oxidation $(\mathrm{mg} / \mathrm{kg} \mathrm{FFM} / \mathrm{d})$ & & \\
Postprandial & & \\
Energy expenditure $(\mathrm{kJ} / \mathrm{kg} \mathrm{FFM} \times 8 \mathrm{~h})$ & $4.31 \pm 1.70$ & $4.07 \pm 2.41$ \\
CHO oxidation $(\mathrm{mg} / \mathrm{kg} \mathrm{FFM} \times 8 \mathrm{~h})$ & $196.25 \pm 94.75$ & $75.88 \pm 74.72^{* *}$ \\
Lipid oxidation $(\mathrm{mg} / \mathrm{kg} \mathrm{FFM} \times 8 \mathrm{~h})$ & $90.93 \pm 80.32$ & $163.68 \pm 108.22^{* *}$ \\
\hline
\end{tabular}

${ }^{*} P<0.05 ;{ }^{* *} P<0.007$. Values are expressed as $M \pm$ s.d. Postprandial energy expenditure and substrates oxidation are expressed as incremental area above the baseline.

carbohydrates and lipids during the standard meal, we calculated the amount of carbohydrate and lipid oxidized as percent of their intake; the amounts of oxidized carbohydrates represented respectively 14 and 5\% of total intake in offspring of two overweight parents and in controls; the corresponding figures for oxidized lipids were respectively 10 and $17 \%$ of total intake in the two groups. The correlation between fasting plasma insulin levels and postprandial lipid oxidation was of borderline statistical significance $(r=-0.46, P=0.05)$.

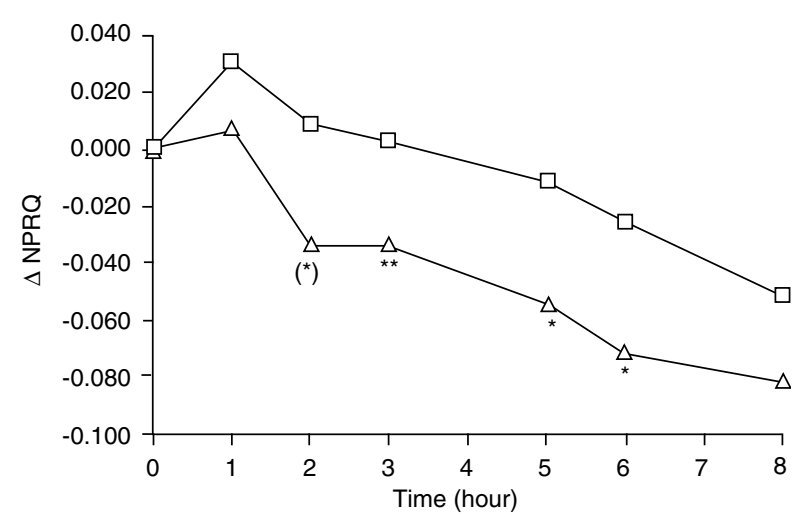

Figure 3 Postprandial changes in NPRQ (expressed as difference between each NPRQ measurement and the baseline value) after the standard fat-rich meal in lean subjects with normal-weight parents (triangle) and in those with both parents overweight (square). ( $\left.{ }^{*}\right) P \cong 0.05$; ${ }^{*} P<0.05$; ${ }^{* *} P<0.03$; subjects with normal-weight parents vs subjects with both parents overweight.

\section{Discussion}

The main finding of this study is that lean offspring of overweight parents, who are at high risk to develop overweight, present a $56 \%$ lower fat oxidation in response to a fat-rich meal and are more insulin sensitive than the offspring of parents having normal weight.

The reduced fat oxidation observed in our study in the group of lean subjects with a strong family history of overweight is in line with the results of previous studies performed in Pima Indians ${ }^{13}$ and in Caucasian volunteers participating in the Baltimore Longitudinal Study on Aging, ${ }^{24}$ where subjects with high RQ (low-fat oxidizers) had a greater risk of gaining weight than those with low RQ (high-fat oxidizers). Our results are also supported by studies performed in both postobese women, in whom a reduced lipid oxidation was demonstrated in response to an increased dietary fat content, ${ }^{12}$ and in obese women before and during weight loss, after refeeding and in the weightrelapse period. ${ }^{14}$ However, resting metabolic rate or the respiratory exchange ratio have not been consistently found as good predictors of subsequent weight changes; ${ }^{10}$ moreover, the studies performed in obese or postobese individuals were unable to explain whether the reduced lipid oxidation is the consequence of a metabolic derangement induced by the pre-existing obesity or the cause that promotes the development of obesity. Our study shows, for the first time, that the reduced capacity to oxidize fat after a fat-rich meal is present also in individuals who are not, and have never been, obese but present a strong family history of overweight and therefore are at high risk to become overweight. Our results suggest that this metabolic abnormality represents an early marker of risk to develop obesity and is, probably, genetically determined.

Multiple genes might be involved in the predisposition to obesity. Two of them are particularly relevant in relation to the metabolic abnormalities observed in this study in the lean offspring of two obese parents: (1) the medium-chain 
acyl-CoA dehydrogenase and (2) leptin receptor. They are both involved in fatty acid oxidation and are located in chromosome 1 in a region in linkage with the $24 \mathrm{~h} \mathrm{RQ} .{ }^{25}$ The evaluation of the role of these and other genes influencing the metabolic abnormalities that we observed in the offspring of two overweight parents was outside the scope of our work. However, the available evidence suggests that their contribution might be less important than that of the environmental factors. ${ }^{10,15}$

In our study the reduced lipid oxidation was not associated with abnormalities of EE either in the fasting state or in the postprandial period. The two groups were also comparable for fasting plasma glucose, cholesterol, triglyceride, HDLcholesterol and FFA concentrations. Conversely, increased postprandial fat oxidation in the offspring of two overweight parents was associated with lower plasma insulin levels, but the mechanism underlying this association is not clear. Since insulin has an important stimulatory influence on fat synthesis and a strong inhibitory effect on lipolysis, it does not seem plausible that low insulin levels represent the primary cause of the metabolic alterations observed in the offspring of two overweight parents. In addition, insulin levels are lower in this group also during the postprandial period and this, if anything, would justify a lower carbohydrate and a higher fat oxidation, which is just the opposite of what we observed. It seems more reasonable to consider low insulin levels as markers of a better insulin sensitivity and to hypothesize, instead, that the lower fat oxidation represents the first step of a chain of events leading to both an increased fat storage - eventually causing overweight - and a higher carbohydrate oxidation - a marker of insulin sensitivity. Alternatively, in the presence of a higher insulin sensitivity, carbohydrates are preferentially oxidized and therefore fat is used predominantly for storage. The cross-sectional nature of this study does not allow us to evaluate the time sequence of these metabolic events.

In support of the role of insulin sensitivity as a marker of risk for overweight, there is a study by Swinburn et $a l^{26}$ performed in Pima Indians - a population at high risk to develop obesity - in which more insulin-sensitive individuals showed a higher rate of weight gain compared with more insulin-resistant ones. Similar observations were reported also in Mexican Americans ${ }^{27}$ and Caucasians; ${ }^{28}$ thus, insulin sensitivity is a predictor of weight gain in adults or, conversely, insulin resistance is associated with lower rates of weight gain. The results of our study, in agreement with previous reports on this topic, seem to indicate that the insulin resistance observed in many obese subjects is a consequence of obesity rather than its primary cause. In addition, our study provides further insight into the mechanisms underlying the risk of becoming overweight by showing that, in the presence of a familial predisposition to obesity, reduced fat oxidation and a better basal insulin sensitivity are both present, thus suggesting a pathophysiological association between these conditions and, furthermore, a link between these two and the development of obesity.
Among the possible hormonal factors influencing weight gain, leptin, a hormone produced by adipose tissue which inhibits food intake and increases $\mathrm{EE},{ }^{29}$ may play a role in the development of obesity in humans. ${ }^{30}$ In our study, plasma leptin levels were slightly lower in the fasting and postprandial period in the group with overweight parents than in the control group, although the difference was not statistically significant.

We can reasonably exclude that the differences in lipid oxidation and insulin sensitivity observed in this study can be attributed to environmental factors and, in particular, to differences in age, physical activity levels or dietary habits between the groups. As a matter of fact, in our study the group with overweight parents was slightly but significantly older than the control group, and since insulin resistance increases through the years, a worse insulin sensitivity was expected in this group because of its older age, whereas our results went in the opposite direction. In addition, the general habitual diet of the two groups was comparable for energy intake and nutrient composition. In particular, total fat intake, saturated fat content and $\mathrm{P} / \mathrm{S}$ ratio were similar, and all participants consumed a standardized identical diet the day before the experiment.

In conclusion, normal-weight subjects with a strong family history of overweight, and therefore at increased risk to become obese, present a reduced lipid oxidation after a high-fat meal and a metabolic profile characterized by low fasting plasma insulin concentrations and a low HOMA index compatible with the presence of increased insulin sensitivity. These metabolic features represent early-and probably genetically determined-predictors of weight gain since they have been observed in young normal-weight individuals who are at high risk to become obese merely by their strong familial predisposition. It is tempting to hypothesize that when exposed to a high-fat diet, individuals with this metabolic background are unable to increase proportionally their fat oxidation leading to an increased fat flux to the adipose tissue for storage and, consequently, to an increase in fat mass.

\section{Acknowledgements}

This work was supported in part by the Italian Ministry of Health, Grant ICS030.11/RS00138". We gratefully acknowledge R Scala for linguistic revision.

\section{References}

1 WHO Consultation in Obesity. Global prevalence and secular trends in obesity. In: World Health Organisation (eds). Obesity preventing and managing the global epidemic. WHO: Geneva; 1998. pp 17-40.

2 The ILSI Europe Overweight and Obesity in Children Task Force. Overweight and obesity in european children and adolescents. Causes and consequences-prevention and treatment. A Report The ILSI Europe Overweight and Obesity in Children Task Force ILSI Europe: Brussels; 2000. 
3 Gordon T, Kannel WB. Obesity and cardiovascular disease: the Framingham Study. J Clin Endocrinol Metab 1976; 5: 367-375.

4 Chan JM, Rimm EB, Coldiz GA, Stampfer MJ, Willet WC. Obesity, fat distribution and weight gain as risk factors for clinical diabetes in men. Diabetes Care 1994; 17: 961-969.

5 Weinsier RL, Hunter GR, Heini AF, Goran MI, Sell SM. The etiology of obesity: relative contribution of metabolic factors, diet, and physical activity. Am J Med 1998; 105: 145-150.

6 Ravussin E, Bogardus C. Energy balance and weight regulation: genetics versus environment. Br J Nutr 2000; 83: S17-S20.

7 Comuzzie A, Allison D. The search for human obesity genes. Science 1998; 280: 1374-1377.

8 Bouchard C, Rice T, Lemieux S, Despés P-J, Perusse L, Rao DC. Major gene for abdominal visceral fat area in Quebec Family Study. Int J Obes Relat Metab Dosord 1996; 20: 420-427.

9 Stunkard AJ, Harris JR, Pedersen NL, McClearn GE. The bodymass index of twins who have been reared apart. $N$ Engl J Med 1990; 322: 1483-1487.

10 Katzmarzyk PT, Pérusse L, Tremblay A, Bouchard C. No association between resting metabolic rate or respiratory exchange ratio and subsequent changes in body mass and fatness: $51 / 2$ year follow-up of the Québec Family Study. Eur J Clin Nutr 2000; 54: 610-614.

11 Tucker LA, Kano MJ. Dietary fat and body fat: a multivariate study of 205 adult females. Am J Clin Nutr 1992; 56: 616-622.

12 Astrup A, Buemann B, Christensen NJ, Toubro S. Failure to increase lipid oxidation in response to increasing dietary fat content in formerly obese women. Am J Physiol 1994; 266: E592-E599.

13 Zurlo F, Lillioja S, Esposito-Del Puente A, Nyomba BL, Raz I, Saad MF, Swinburn BA, Knowler WC, Bogardus C, Ravussin E. Low ratio of fat to carbohydrate oxidation as predictor of weight gain: study of $24 \mathrm{~h}$ RQ. Am J Physiol 1990; 259: E650-E657.

14 Froidevaux F, Schutz Y, Christin L, Jéquier E. Energy expenditure in obese women before and during weight loss, after refeeding and in the weight-relapse period. Am J Clin Nutr 1993; 57: 35-42.

15 Whitaker R, Wright JA, Pepe MS, Seidel KD, Dietz WH. Predicting obesity in young adulthood from childhood and parental obesity. N Engl J Med 1997; 337: 869-873.

16 Istituto Nazionale di Ricerca per gli Alimenti e la Nutrizione. Tabelle di composizione degli alimenti. EDRA Medical Publishing \& New Media: Milan, Italy; 2000.

17 Annuzzi G, Vaccaro O, Caprio S, Di Bonito P, Caso P, Riccardi G, Rivellese A. Association between low habitual physical activity and impaired glucose tolerance. Clin Physiol 1985; 5: 63-70.
18 Jones PJH, Ridgen JE, Phang PT, Birmingham CL. Influence of dietary fat polyunsaturated to saturated ratio on energy substrate utilization in obesity. Metabolism 1992; 41: 396-401.

19 Weir JbdeV. New methods for calculating metabolic rate with special reference to protein metabolism. I Physiol 1949; 109: 1-9.

20 Kotler DP, Burastero S, Wang J, Pierson Jr RN. Prediction of body cell mass, fat-free mass, and total body water with bioelectrical impedance analysis: effects of race, sex, and disease. Am J Clin Nutr 1996; 64: 489S-497S

21 Lukaski HC, Bolonchuk WW, Hall CB, Siders WA. Validation of tetrapolar bioelectrical impedance method to assess human body composition. J Appl Physiol 1986; 60: 1327-1332.

22 Ma Z, Gingerich RL, Santiago JV, Klein S, Smith CH, Landt M. Radioimmunoassay of leptin in human plasma. Clin Chem 1996; 42: 942-946.

23 Matthews DR, Hosker JP, Rudenski AS, Naylor BA, Treacher DF, Turner RC. Homeostasis model assessment: insulin-resistance and B-cell function from fasting plasma glucose and insulin concentrations in man. Diabetologia 1985; 28: 412-419.

24 Seidell JC, Muller DC, Sorkin JD, Andres R. Fasting respiratory exchange ratio and resting matabolic rate as predictor of weight gain: the Baltimore Longitudinal Study of Aging. Int J Obes Relat Metab Disord 1992; 16: 667-674.

25 Norman RA, Tataranni PA, Pratley R, Thompson DB, Hanson RL, Prochazca M, Baier L, Ehm MG, Sakul H, Foroud T, Garvey WT, Burns D, Knowler WC, Bennett PH, Bogardus C, Ravussin E. Autosomal genomic scan for loci linked to obesity and energy metabolism in Pima Indians. Am J Hum Genet 1998; 62: 659-668.

26 Swinburn BA, Nyomba BL, Saad MF, Zurlo F, Raz I, Knowler WC, Lillioja S, Bogardus C, Ravussin E. Insulin resistance associated with lower rates of weight gain in Pima Indians. J Clin Invest 1991; 88: $168-173$.

27 Valdez R, Mitchell BD, Haffner SM, Hazuda HP, Morales PA, Monterosa A, Stern MP. Predictors of weight change in bi-ethnic population: the San Antonio Heart Study. Int J Obes Relat Metab Disord 1994; 18: 85-91.

28 Hoag S, Marshall JA, Jones RH, Hamman RF. High fasting insulin levels associated with lower rates of weight gain in persons with normal glucose tolerance: the San Luis Valley Diabetes Study. Int J Obes Relat Metab Disord 1995; 19: 175-180.

29 Caro JF, Sinha MK, Kolaczynski JW, Zhang PL, Considene RV. Leptin: the tale of an obesity gene. Diabetes 1997; 45: 1455-1462.

30 Ravussin E, Pratley RE, Maffei M, Wang H, Friedman JM, Bennet $\mathrm{PH}$, Bogardus C. Relatively low plasma leptin concentrations precede weight gain in Pima Indians. Nat Med 1997; 3: 238-240. 